\title{
A multi-approach analysis of the genetic diversity in populations of Astyanax aff. bimaculatus Linnaeus, 1758 (Teleostei: Characidae) from Northeastern Brazil
}

\author{
Vanessa de Carvalho Cayres Pamponet ${ }^{1}$, Paulo Luiz Souza Carneiro ${ }^{2}$, Paulo Roberto \\ Antunes de Mello Affonso ${ }^{2}$, Viviam Souto Miranda², Juvenal Cordeiro Silva Júnior², \\ Claudine Gonçalves de Oliveira ${ }^{1}$ and Fernanda Amato Gaiotto ${ }^{1}$
}

Few reports are available about the ichthyofauna of typical semi-arid rivers, although the regional diversity has been constantly threatened by human activities, mainly related to impoundment and construction of dams. The goal of the present work was to evaluate using different methods, the population genetic structure of a characin fish, Astyanax aff. bimaculatus, widespread throughout hydrographic basins of Bahia, Northeastern Brazil. Morphological (meristic and morphometric data), cytogenetic (karyotype and Ag-NOR), and molecular (RAPD and SPAR) analyses were carried out in specimens collected upstream and downstream of Pedra Dam, in the main channel of Contas River (Contas River Basin), and in the Mineiro stream, which belongs to the adjacent Recôncavo Sul basin. Few external differences were detected among populations, where the individuals collected upstream of Pedra Dam were slightly larger than the others. Cytogenetic data also showed a similar karyotypic pattern $(2 \mathrm{n}=50 ; 6 \mathrm{~m}+28 \mathrm{sm}+12 \mathrm{st}+4 \mathrm{a}$; $\mathrm{FN}=96$ ) and NORs located on the short arms of up to two chromosome pairs, with numerical inter- and intra-populational variation. Nonetheless, RAPD and SPAR analyses differentiated reliably the three populations, revealing striking differences in the allele frequencies among the localities studied and a significant difference in population structure index $\left(\mathrm{F}_{\mathrm{st}}=0.1868, \mathrm{P}<0.0001\right)$. The differences between populations within a same river were as significant as those between distinct hydrographic basins, indicating that the dam/reservoir represents an effective barrier to gene flow. Additionally, environmental peculiarities from each locality are also believed to influence the genetic patterns detected herein. On the other hand, the similarity between samples from Contas River and Recôncavo Sul basins could be related to a common evolutionary history, since both basins are geographically close to each other. Finally, the present study shows that a multi-approach analysis is particularly useful in identifying the population structure of widely distributed species and to evaluate the impacts of human activities on natural fish populations.

Poucos estudos ictiofaunísticos estão disponíveis em rios típicos do semi-árido, apesar da constante ameaça à diversidade local devido a influências antrópicas, com destaque para o represamento e construção de barragens. O presente trabalho teve como objetivo avaliar, por meio de diferentes metodologias, a estrutura genética de populações de uma espécie de caracídeo, Astyanax aff. bimaculatus, amplamente distribuída em bacias hidrográficas da Bahia, Nordeste do Brasil. Análises morfológicas (dados merísticos e morfométricos), citogenéticas (cariótipo e Ag-RONs) e moleculares (RAPD e SPAR) foram realizadas em espécimes coletados à montante e à jusante da Barragem da Pedra, na calha principal do médio rio de Contas (bacia do Rio de Contas) e no ribeirão Mineiro, pertencente à bacia adjacente do Recôncavo Sul. Poucas diferenças externas foram detectadas entre as populações, sendo os indivíduos originários do reservatório, à montante da barragem, ligeiramente maiores. Os dados citogenéticos também mostraram padrões cariotípicos semelhantes $(2 \mathrm{n}=50 ; 6 \mathrm{~m}+28 \mathrm{sm}+12 \mathrm{st}+4 \mathrm{a} ; \mathrm{FN}=96)$ e RONs situadas nos braços curtos de até dois pares cromossômicos, com variação numérica inter- e intra-populacional. Contudo, as análises por RAPD e SPAR diferenciaram as três populações de forma eficiente, revelando freqüências alélicas significativamente diferentes entre as localidades amostradas e índices significativos de estruturação populacional $\left(\mathrm{F}_{\mathrm{st}}=0.1868, \mathrm{P}<0.0001\right)$. As diferenças entre populações do mesmo rio foram tão significativas quanto entre bacias hidrográficas distintas, indicando que a represa constitui uma barreira eficiente ao fluxo gênico. Além disso, acredita-se que peculiaridades ambientais de cada localidade possam também influenciar os padrões genéticos encontrados. Por outro lado, a similaridade entre amostras das bacias do Rio de Contas e Recôncavo Sul pode estar relacionada a uma história evolutiva comum, já que ambas estão geograficamente próximas. Por fim, o presente estudo demonstra que a realização de estudos envolvendo diferentes marcadores é extremamente útil para a identificação de estruturas de populações em espécies amplamente distribuídas e para avaliação dos impactos das atividades humanas sobre as populações naturais de peixes.

Key words: Morphometry, Cytogenetics, RAPD, Population structure, Contas River.

\footnotetext{
'Universidade Estadual de Santa Cruz, Dep. Ciências Biológicas. Rodovia Ilhéus-Itabuna, km 16, 45662-000, Ilhéus, BA, Brazil. ${ }^{2}$ Universidade Estadual do Sudoeste da Bahia, Dep. Ciências Biológicas. Av. José Moreira Sobrinho, s/n., 45206-510, Jequié, BA, Brazil. paulomelloaffonso@yahoo.com.br
} 


\section{Introduction}

The Contas River hydrographic basin is entirely located in the state of Bahia, Northeastern Brazil $\left(12^{\circ} 55^{\prime}\right.$ to $15^{\circ} 30^{\prime} \mathrm{S}$, $39^{\circ} 00^{\prime}$ to $42^{\circ} 35^{\prime} \mathrm{W}$ ), comprising a drainage area of 64,933 $\mathrm{km}^{2}$, and limited by the Recôncavo Sul, Paraguaçu, São Francisco, Pardo and Eastern hydrographic basins. Its headwaters originate in the Diamantina Plateau (about 1,500 m high) and flow over $620 \mathrm{~km}$ before reaching the Atlantic Ocean, encompassing several small to large riverine systems, waterfalls and a high urban concentration (SRHSH, 1993; CRA, 2001; MMA, 2006a). The Contas River Basin is influenced by an array of climate types, ranging from humid to dry. A tropical rain climate is found along the coast and it becomes progressively drier inland, where it shows semi-arid characteristics. Therefore, three physiogeographic regions can be distinguished along this basin: upper, middle and lower Contas River, characterized by semi-arid (Caatinga biome), semi-arid/ tropical transition and humid climates (Atlantic rain forest), respectively (SRHSH, 1993; MMA, 2006b).

Contas River is the main river of this hydrographic basin and represents one of the most important water systems in the state of Bahia (CRA, 2002; MMA, 2006b). However, little is known about the ichthyofauna of this river and its tributaries, even though several human activities are likely to affect the local fish assemblages.

In the sixties, a large reservoir (Pedra Dam) was built in the main channel of the Contas River, near the municipality of Jequié (semi-arid belt, middle Contas region) in order to control floods and impound water for dry periods and power supply. This reservoir has a water surface of nearly $70 \mathrm{~km}$ and a storage capacity of 1.7 billion cubic meters (SRHSH, 1993; MMA, 2006b).

By damming the rivers, their typical lotic features are affected, with consequent losses and formation of new habitats (Paiva, 1982; Vono et al., 2002). The ecotone mosaic within the impounded waters of a reservoir modify the spatial and temporal patterns of fish communities, such as trophic structure, ecological guilds and species diversity (Pianka, 1974; Winemiller \& Leslie, 1992; Welcomme et al., 2005). Moreover, the construction of dams creates a new obstacle to gene flow among populations of aquatic organisms located upstream and downstream of dams, leading to alterations in gene frequencies (Avise \& Felley, 1979). The constraints in dispersal and gene flow can affect intra- and inter-populational diversity levels, mainly of migratory species (Agostinho et al., 1992; Godinho \& Godinho, 1994; Vrijenhoek, 1998; Hatanaka \& Galetti, 2003).

Although the small characin fish Astyanax bimaculatus (Linnaeus, 1758) actually refers to specimens from Suriname, the so-called "bimaculatus-group" comprises at least 15 species of generalist and migratory fish, well adapted to both running and stagnant waters and widely distributed throughout Brazilian rivers (Esteves \& Galetti, 1995; Agostinho et al., 1997; Garutti \& Britski, 2000). Recent morphological studies have separated this group into distinct species such as
Astyanax altiparanae from upper Paraná River, Brazil, but most still lack a proper nomination (Garutti, 1998; Garutti \& Britski, 2000). Genetic studies carried out in this widespread and closely related group of species have been helpful in understanding the population structure and patterns of geographic isolation, thus providing a baseline for management and conservation programs (Paiva et al., 2006; Domingues et al., 2007; Kantek et al., 2007; Pazza et al., 2007 among others). Such studies, comprising an array of methods from morphology to cytogenetic and molecular markers, are particularly important to estimate the impact of human activities and environmental effects on Neotropical fish assemblages. However, these features remain unknown along hydrographic basins in the semi-arid region.

In order to evaluate the genetic structure of Astyanax aff. bimaculatus along Contas River Basin, morphometric, cytogenetic, and molecular studies were performed in populations located upstream and downstream of Pedra Dam (middle Contas River). Another population, from an adjacent hydrographic basin (Recôncavo Sul) was also included in the present work for comparative analyses. These data are discussed based on environmental peculiarities and geographic isolation of each collection site.

\section{Material and Methods}

Sampling sites. Specimens of $A$. aff. bimaculatus were collected using gillnets at three localities: two collection sites in the main channel of the middle Contas River (Contas River Basin), and one in Mineiro stream (Recôncavo Sul Basin). Samples from the Contas River were obtained in the reservoir, $70 \mathrm{~km}$ upstream of Pedra Dam, in the city of Maracás, Porto Alegre County (1352' $5^{\prime \prime} \mathrm{S}, 40^{\circ} 14^{\prime} 9^{\prime \prime} \mathrm{W}, 230 \mathrm{~m}$ above sea level, site A) and nearly $25 \mathrm{~km}$ downstream of Pedra Dam,

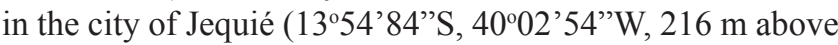
sea level, site B). The sampling in Mineiro stream was carried out in the city of Itamari, Mineiro County, at $63 \mathrm{~km}$ from Jequié (1360'54”'S, 3941'54'W, $285 \mathrm{~m}$ above sea level, site C) (Figs. 1-2).

Fish samples were transported to the laboratory and kept in separated tanks prior to morphometric, cytogenetic and molecular analyses. Voucher specimens were identified by Dr. Luiz R. Malabarba (UFRGS, Porto Alegre, RS) and deposited in the fish collection at Universidade Estadual do Sudoeste da Bahia (identification numbers: MN198-202, MN204-208, PA236-241, RC311-317).

Morphological studies. Eighty-four specimens were collected for meristic and morphometric analyses (Table 1). The meristic characteristics considered were the number of scales in the lateral line (LLS), number of rays in the anal fin (AFR) and number of rays in the dorsal fin (DFR), according to Garutti (1998). Variance analysis (á $=5 \%$ ) was performed to compare the average meristic values, using the GLM procedure in the software SAS (2004). The morphometric characters were: total length, head length, body height, caudal peduncle height, 

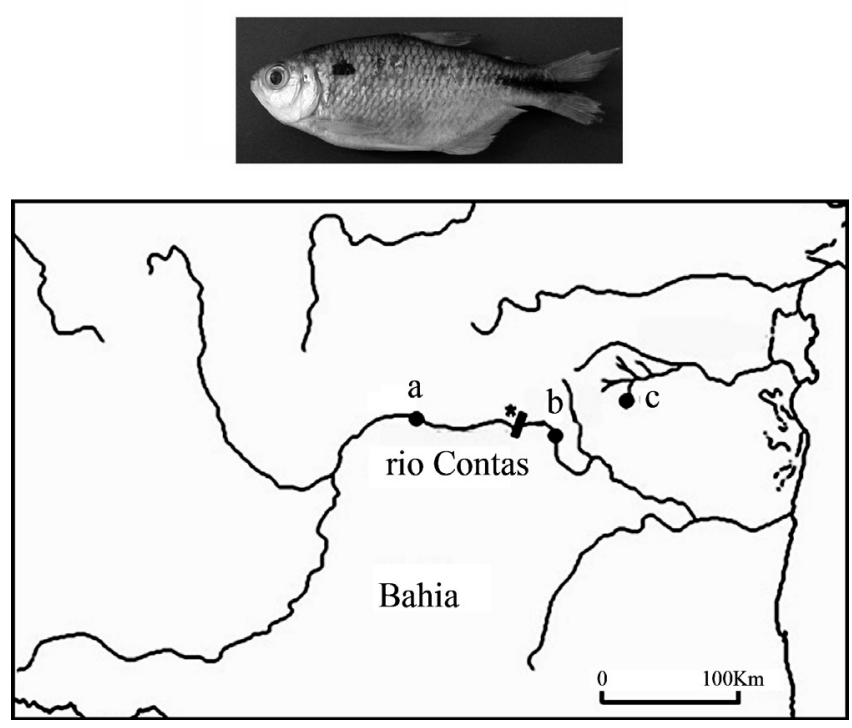

Fig. 1. Map of the studied area in the State of Bahia, Brazil, showing the hydrographic system and collection sites of $\mathrm{As}$ tyanax aff. bimaculatus: (a) site A - Contas River, upstream of Pedra Dam, Porto Alegre County (b) site B - Contas River, downstream of Pedra Dam, city of Jequié (Contas River Basin), (c) site C - Mineiro stream, city of Itamari (Recôncavo Sul Basin) and (*) location of Pedra Dam in Contas River. A specimen of Astyanax aff. bimaculatus is illustrated in detail (total length $=6.65 \mathrm{~cm})$.

interorbital width, ocular diameter, preanal length, predorsal length, head height, and distances between dorsal and pectoral fins, pectoral and pelvic fins, pelvic and anal fins, dorsal and anal fins, anal and adipose fins, and dorsal and adipose fins (Lagler et al., 1977). The morphometric data were converted to body proportions and expressed in percentage in order to indicate the relationship between total length, head length, body height and other morphometric measurements.

Cytogenetic studies. Two males and 3 females of $A$. aff. $b i$ maculatus from site A (Contas River, upstream Pedra Dam), 11 males and 8 females from site B (Contas River, downstream of Pedra Dam), and 17 individuals, including 5 males, 11 females and one unidentified, from site $\mathrm{C}$ (Mineiro stream) were cytogenetically analyzed (Table 1). Mitotic stimulation was performed on collected specimens $72 \mathrm{~h}$ prior to cytogenetic procedures, as described by Molina (2001). Metaphasic chromosomes were obtained from kidney cells according to Bertollo et al. (1978). The slides were stained with 5\% Giemsa for conventional analyses. The nucleolar organizer regions were detected by silver nitrate staining (Ag-NOR) (Howell and Black, 1980). The best metaphases were photographed in Imagelink Kodak ${ }^{\mathrm{TM}}$ ISO 25 for chromosomal measurements, karyotyping and NOR analysis. The chromosome pairs were arranged in decreasing size order and classified as metacentric (M), submetacentric (SM), subtelocentric (ST) and acrocentric (A) (Levan et al., 1964).
Molecular studies. Tissue samples were obtained from epaxial muscle or gill filaments of about 25 specimens per collection site (Table 1) and fixed in $95 \%$ ethanol prior to molecular analyses. DNA extraction followed the CTAB protocol reported by Boyce et al. (1989), with slight modifications. The amplification reactions were performed according to Williams et al. (1990), comprising a final volume of $13 \mathrm{ml}\left(3.42 \mathrm{ml} \mathrm{H}_{2} \mathrm{O}\right.$; $1.3 \mathrm{ml} \mathrm{10x}$ buffer with $1 \mathrm{M} \mathrm{MgCl}_{2}, 1.04 \mathrm{ml} 2.5 \mathrm{mM}$ dNTP; $1.05 \mathrm{ml}$ bovine serum albumin, $3 \mathrm{ml}$ primer at $2.5 \mathrm{mM}, 0.2$ $\mathrm{ml} 5 \mathrm{U} / \mathrm{ml}$ Taq polymerase and $3 \mathrm{ml}$ of $2.5 \mathrm{ng}$ template DNA). PCR reactions were carried out in a Mastercycler Gradient Eppendorf thermocycler with one initial heating step at $92^{\circ} \mathrm{C}$ for $2 \mathrm{~min}, 40$ cycles at $92^{\circ} \mathrm{C}$ for $1 \mathrm{~min}, 35^{\circ} \mathrm{C}$ for $1 \mathrm{~min}$ and $72^{\circ} \mathrm{C}$ for $2 \mathrm{~min}$, followed by a final extension step at $72^{\circ} \mathrm{C}$ for 5 min. The amplified products were run for $3 \mathrm{~h}$ at $110 \mathrm{~V}$ in $1.5 \%$ agarose gel and stained with ethidium bromide. The fragments were visualized under ultraviolet light and photographed for further analyses. The fragment size was estimated using a 1-kb molecular weight ladder (Fermentas Life Technologies).

Fifty RAPD and 17 SPAR primers (both provided by Operon Technologies) were screened. The rate of missing values per marker was estimated and the primers showing more than $25 \%$ of unrecorded data were excluded. Therefore, six RAPD primers (OPA-18, OPA-20, OPA-02, OPA-09, OPA-11, OPD-02) and five SPARs (SPAR1, SPAR2, SPAR17 SPAR16, SPAR15) were selected, since they produced an adequate number of scorable, polymorphic, and well-defined bands. Each individual was codified as a string of 1 and 0 indicating the presence or absence of amplification products and data entered into a binary matrix, assuming that each band represented a Mendelian locus of dominant behavior with a non-detectable recessive allele (Lynch \& Milligan, 1994). The software ARLEQUIN (Schneider et al., 2000) was used to perform the analysis of molecular variance (AMOVA) and to estimate the inter-population variation by providing $\mathrm{F}_{\text {st }}$ values, considered the best parameters of population structure for RAPD studies (Excoffier et al., 1992; Hartl \& Clark, 1997). According to Wright (1978), values of 0 to 0.05 indicate little genetic differentiation, 0.05 to 0.15 indicates moderate differentiation; 0.15 to 0.25 suggests a high differentiation, and values over 0.25 represent a very high genetic differentiation. The proportion of polymorphic loci and degree of population differentiation using Fisher's Exact test were carried out using the software TFPGA - Tools For Population Genetic Analysis (Miller, 1997).

Table 1. Localities and sample sizes of Astyanax aff. bimaculatus for morphologic $\left(\mathrm{N}_{1}\right)$, cytogenetic $\left(\mathrm{N}_{2}\right)$, and molecular $\left(\mathrm{N}_{3}\right)$ analyses (*Contas River Basin, ** Recôncavo Sul Basin).

\begin{tabular}{llccc}
\hline Samples (sites) & Locality & $\mathrm{N}_{1}$ & $\mathrm{~N}_{2}$ & $\mathrm{~N}_{3}$ \\
\hline Contas River (A)* & Upstream Pedra Dam, Porto Alegre & 30 & 5 & 24 \\
& County & & & \\
Contas River (B)* & Downstream Pedra Dam, Jequié & 24 & 19 & 25 \\
Mineiro stream (C)*** & Mineiro County, Itamari & 30 & 17 & 24 \\
\hline Total & & 84 & 41 & 73 \\
\hline
\end{tabular}



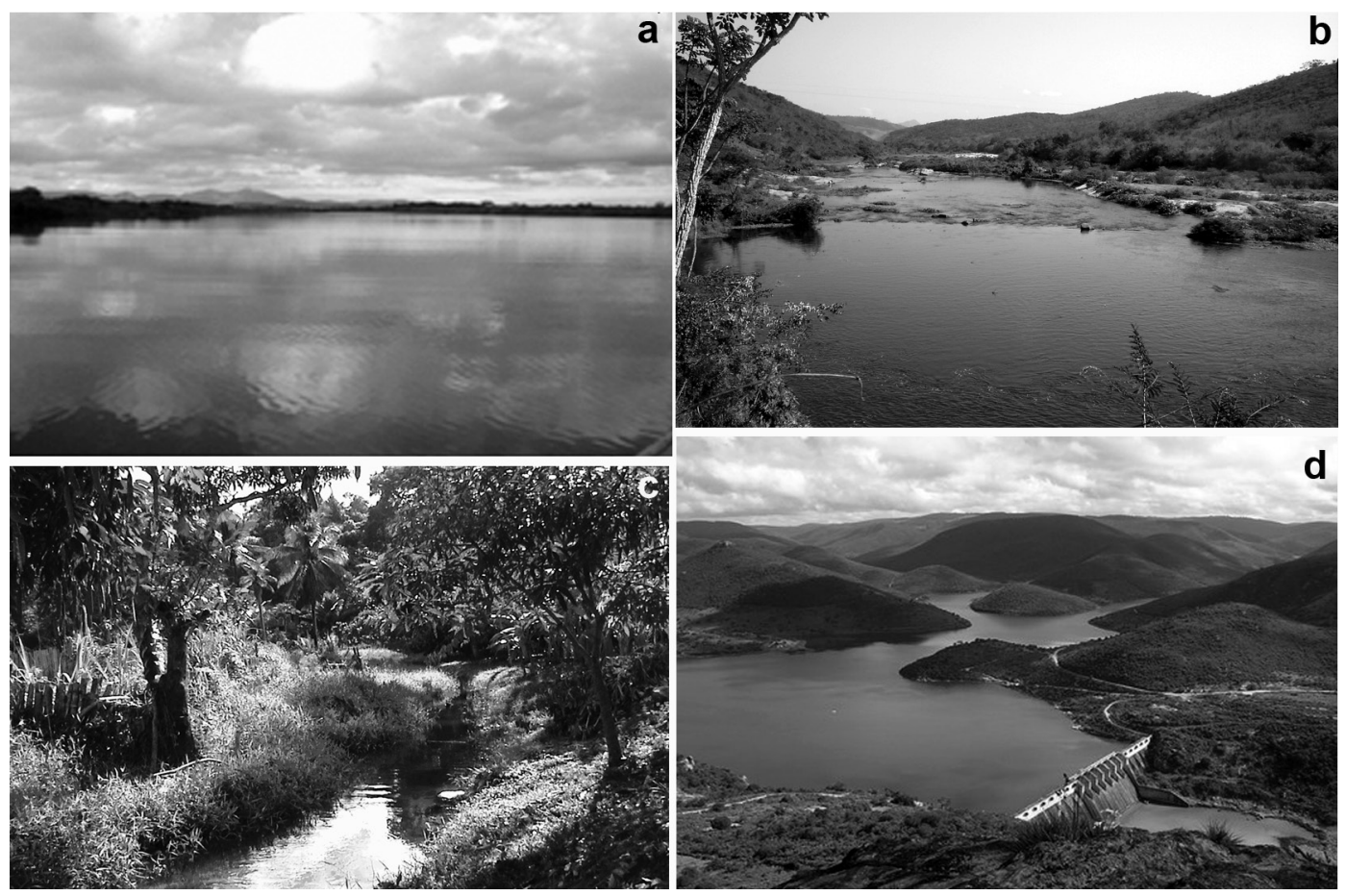

Fig. 2. Partial view of collection sites of Astyanax aff. bimaculatus in the State of Bahia, Brazil: (a) Contas River, upstream Pedra Dam, Porto Alegre County - site A, (b) Contas River, downstream Pedra Dam, city of Jequié - site B, and (c) Mineiro stream, Recôncavo Sul Basin, city of Itamari - site C. In (d), view of Pedra Dam reservoir in Middle Contas River, city of Jequié.

\section{Results}

Morphological studies. The mean and standard deviation values for the number of lateral line scales (LLS), and number of rays in the anal (AFR) and dorsal fins (DFR) of each $A$. aff. bimaculatus population are shown in Table 2. Such meristic features demonstrated little or no variation (e.g. DFR) among distinct collection sites, with a modal number of 33, 26 and 11 for LLS, AFR and DFR, respectively. Variance analysis also supported this finding, revealing no population effects in relation to the characteristics examined $(\mathrm{P}>0.05)$.

Analyzing the mean absolute values for total length, head length and body height, we observed that specimens from the reservoir (site A) displayed higher values than individuals from other localities, thus supporting empirical findings that fish upstream of Pedra Dam were usually larger. However, inter-population differences were remarkably small when comparing percentage values in relation to total length, head length and body height. The only exceptions include the proportion between interorbital width, head height and head length, and between the caudal peduncle height and body height (Table 3).

Cytogenetic studies. The diploid number found in the three populations of $A$. aff. bimaculatus was equal to $2 \mathrm{n}=50$. A similar karyotype, composed of 6 metacentric, 28 submetacentric, 12 subtelocentric and 4 acrocentric chromosomes $(\mathrm{FN}=96)$ was observed in both males and females from all collection sites (Figs. 3a-c).
Silver nitrate staining revealed an intra- and inter-individual polymorphism in the number of NOR-bearing chromosomes within populations of $A$. aff. bimaculatus. Positive signals, ranging from one to four Ag-NOR sites, were located in the telomeric region on short arms of SM/ST chromosome pairs (Fig. 3d) in all populations studied.

Molecular studies. The percentage of polymorphic loci in the three populations of $A$. aff. bimaculatus ranged from $85.71 \%$ in both Contas River samples (sites A and B) to $100 \%$ in Mineiro stream (site C). Based on Fisher's exact test, $42.8 \%$ (12) of the 28 loci analyzed showed significant differences $(\mathrm{P}<0.05)$ among collection sites. The populations were also significantly different when information from all loci were considered $(\mathrm{P}<0.0001)$.

The amount of genetic variability among and within the three populations of $A$. aff. bimaculatus inferred by analysis of molecular variance (AMOVA) was equal to 18.69 and $81.31 \%$, respectively, with significant values. Although intra-population variation was responsible for most of the genetic diversity in the studied samples, a high genetic differentiation was detected $\left(\mathrm{F}_{\mathrm{st}}\right.$ $=0.1868, \mathrm{P}<0.0001)$, indicating a population structure in $A$. aff. bimaculatus from the Northeastern river basins (Table 4).

Pairwise comparisons based on AMOVA also revealed highly significant divergences $(\mathrm{P}<0.0001)$. A divergence level of $22.02 \%$ was detected between populations upstream and downstream of Pedra Dam (sites A and B, respectively). A lower divergence (about 13\%) was found between populations from site A (Pedra Dam reservoir, Contas River Basin) and site C (Mineiro stream, Recôncavo Sul Basin) (Table 5). 


\section{Discussion}

Studies on the ichthyofauna of Northeastern Brazil still lack a detailed characterization and semi-arid regions, such as Caatinga (dry shrubland), have been formerly regarded as low diversity ecosystems. Nevertheless, a high level of endemism has been suggested for some fish groups inhabiting this biome, as a response to specific evolutionary processes provided by peculiar climate and hydrological features (Rosa, 2004; Rapini et al., 2006). For instance, recent studies reported nearly 240 fish species in semi-arid riverine systems, $57 \%$ of them being endemic (Rosa et al., 2003).

Besides the scarce information about regional fish fauna, many hydrographic basins in the semi-arid region are also threatened by environmental disturbances. The construction of dams and reservoirs are likely to decrease the local biodiversity before we even get to know it. Dams are able to disrupt the gene flow between upstream and downstream aquatic populations and affect the dispersal rate of several migratory fish (Avise \& Felley, 1979; Agostinho et al., 1992; MMA, 2006a). They are responsible for changes in the water flow within a hydrographic system, with consequent losses of original habitats (Vono et al., 2002). Under specific circumstances, the reservoirs may lead to local extinction of populations unable to adapt to the drastic environmental modifications imposed (Godinho \& Godinho, 1994). As a result, the constraints on dispersal, gene flow and fitness usually affect both inter- and intra-populational diversity (Vrijenhoek, 1998).

Actually, the localities selected in the present study are among several other hydrographic systems throughout the eastern Atlantic basin that have been deeply disturbed by human activities (CRA, 2002; MMA, 2006b). These practices have certainly altered natural ecosystems to an unknown extent. Such may be the case of the Pedra Dam in the middle portion of Contas River (Jequié-BA) (Paiva, 1982; SRHSH, 1993; MMA, 2006a).

The morphological analyses in populations of $A$. aff. $b i$ maculatus from the Contas and Recôncavo Sul basins revealed a remarkable homogeneity of both meristic and morphometric characters among individuals, regardless of the collection site. Few exceptions to this pattern were observed, such as the differential proportion of the caudal peduncle height in the Recôncavo Sul sample. Moreover, specimens collected upstream of Pedra Dam (Porto Alegre County, site A) were, on average, larger than those from other samples (Table 3). Similarly, morphological analyses in allopatric populations of Astyanax altiparanae from upper Paraná River Basin revealed several overlaps among measurements in individuals at distinct sites but significant differences were observed regarding the caudal peduncle height (Domingues et al., 2007). These data suggest that such morphometric character could be a valuable parameter in distinguishing, morphologically, populations in these fish groups.

The apparent lack of a remarkable morphological differentiation as observed in the samples of $A$. aff. bimaculatus
Table 2. Mean and standard deviation values for the number of lateral line scales (LLS), rays in the anal fin (AFR) and rays in the dorsal fin (DFR) of each population of Astyanax aff. bimaculatus (*Contas River Basin, ** Recôncavo Sul Basin).

\begin{tabular}{lccc}
\hline Collection sites & LLS & AFR & DFR \\
\hline Contas River, upstream & $33.13 \pm 0.43$ & $26.63 \pm 0.85$ & $11.00 \pm 0.00$ \\
Pedra Dam (A)* & & & \\
Contas River, downstream & $32.61 \pm 0.62$ & $26.09 \pm 1.10$ & $11.00 \pm 0.00$ \\
Pedra Dam (B)* & & & \\
Mineiro stream (C)** & $32.49 \pm 0.60$ & $25.85 \pm 0.83$ & $11.00 \pm 0.00$ \\
\hline
\end{tabular}

Table 3. Mean morphometric data and body proportions of Astyanax aff. bimaculatus.

\begin{tabular}{|c|c|c|c|}
\hline Character & Site A & Site B & Site C \\
\hline Total length $(\mathrm{mm})$ & 74.90 & 69.47 & 69.46 \\
\hline Head length (mm) & 18.20 & 17.44 & 17.89 \\
\hline Body height (mm) & 29.89 & 28.02 & 27.94 \\
\hline \multicolumn{4}{|c|}{ Percentage of total length $(\%)$} \\
\hline Head length & 24.36 & 25.15 & 25.78 \\
\hline Body height & 39.81 & 40.39 & 40.25 \\
\hline Caudal peduncle height & 12.38 & 12.58 & 12.44 \\
\hline Predorsal length & 52.42 & 53.02 & 52.67 \\
\hline Preanal length & 67.95 & 66.31 & 66.40 \\
\hline Dorsal-pectoral fin distance & 43.80 & 43.65 & 42.89 \\
\hline Dorsal-anal fin distance & 41.92 & 42.14 & 41.83 \\
\hline Anal-adipose fin distance & 37.49 & 37.69 & 37.38 \\
\hline Dorsal-adipose fin distance & 38.29 & 38.30 & 39.54 \\
\hline \multicolumn{4}{|c|}{ Percentage of head length (\%) } \\
\hline Ocular diameter & 31.51 & 31.71 & 31.15 \\
\hline Interorbital width & 41.94 & 39.48 & 38.80 \\
\hline Head height & 97.96 & 103.23 & 104.5 \\
\hline \multicolumn{4}{|c|}{ Percentage of body height (\%) } \\
\hline Caudal peduncle height & 31.20 & 31.18 & 44.48 \\
\hline
\end{tabular}

Table 4. Analysis of molecular variance for the three populations of Astyanax aff. bimaculatus studied (all values showed statistically significant differences, $\mathrm{P}<0.0001$ ).

\begin{tabular}{lcccc}
\hline Source of variation & DF & $\begin{array}{c}\text { Mean } \\
\text { square }\end{array}$ & $\begin{array}{c}\text { Variance } \\
\text { components }\end{array}$ & $\begin{array}{c}\text { Variation rate } \\
(\%)\end{array}$ \\
\hline Among populations & 2 & 30.365 & 1.03302 & 18.69 \\
Within populations & 72 & 4.495 & 4.49464 & 81.31 \\
Total & 74 & 5.192 & 5.52766 & 100.0 \\
$\mathrm{~F}_{\mathrm{ST}}=0.1868$ & & & & \\
\hline
\end{tabular}

Table 5. Percentage of genetic variability in pairwise comparisons of Astyanax aff. bimaculatus populations, as estimated by analysis of molecular variance (all values showed statistically significant differences, $\mathrm{P}<0.0001)$.

\begin{tabular}{lcc}
\hline Collection sites & A & B \\
\hline A (Contas River, upstream Pedra Dam) & - & - \\
B (Contas River. Downstream Pedra Dam) & 22.02 & - \\
C (Mineiro stream) & 13.03 & 20.28 \\
\hline
\end{tabular}

studied could indicate that populations, mainly within the same basin, are connected. Nonetheless, it should be recalled that morphological variations within several fish species become detectable when considered over large geographical distances (e.g., Molina et al., 2006) or in the presence of highly effective geographic barriers. For instance, Paiva et al. (2006) analyzed meristic characters in populations of $A$. bimaculatus from the Doce River Basin and found significant differences based on F statistics $(\mathrm{P}<0.05)$ between samples from the Santana and Casca rivers, currently separated by Grande Falls. This wa- 

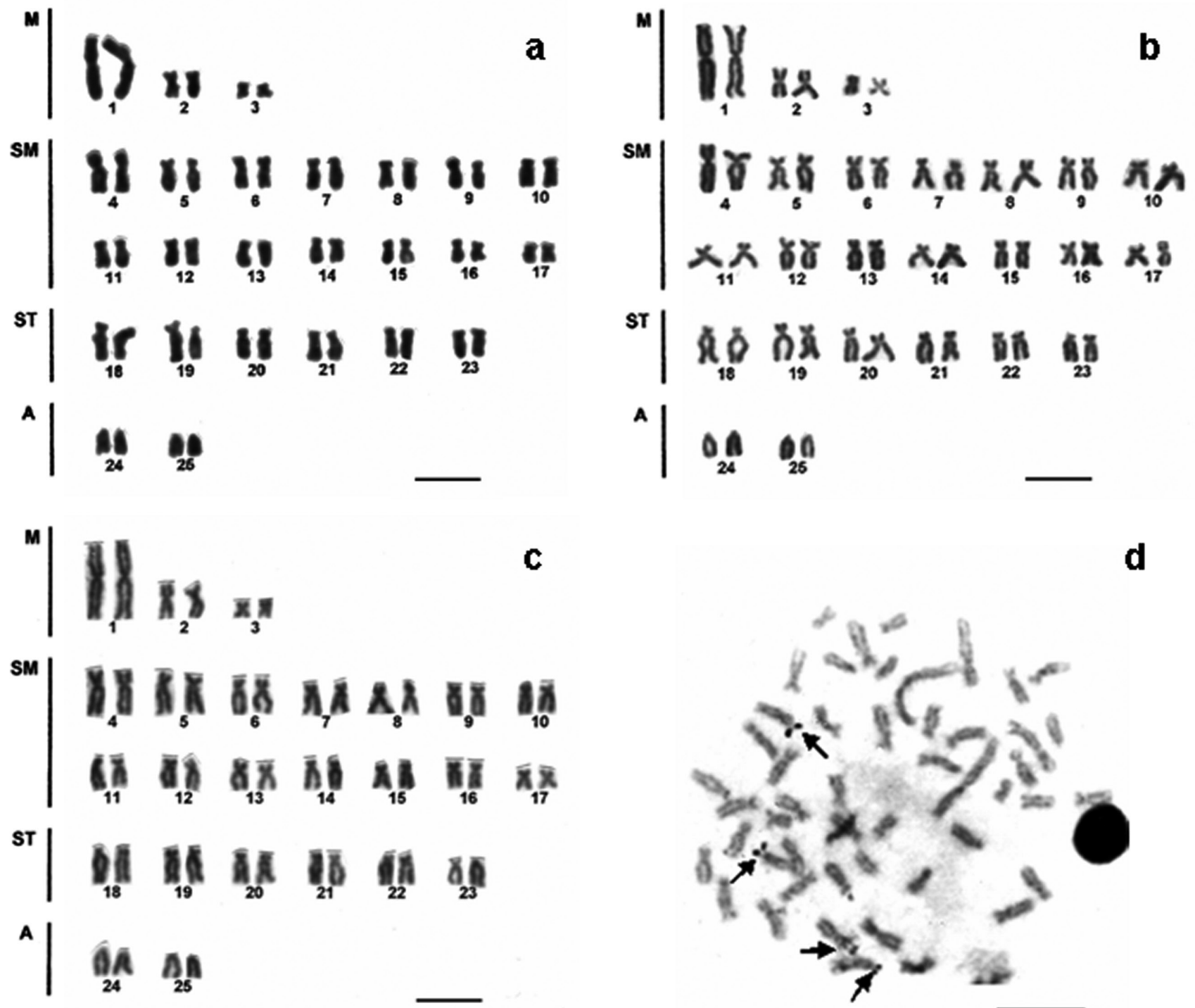

Fig. 3. Giemsa-stained karyotypes of Astyanax aff. bimaculatus $(2 \mathrm{n}=50, \mathrm{FN}=96)$ from sites $\mathrm{A}(\mathrm{a}), \mathrm{B}$ (b) and C (c). In (d), a somatic metaphase after silver nitrate staining in a specimen from Contas River, showing four positive signals (arrows). The bar equals $5 \mu \mathrm{m}$.

terfall is the largest $(15 \mathrm{~m})$ within the sample range and could represent a effective barrier between populations by affecting the survival of eggs and larvae flowing downstream. In some cases, even genetically distinguishable populations can keep their morphological resemblance, as corroborated by the absence of visible morphological differences in individuals of Astyanax fasciatus from the Mogi-Guaçu River bearing distinct cytotypes (Pazza et al., 2007).

On the other hand, some morphometric studies in other Astyanax representatives can reveal a high degree of differentiation, such as the one observed in samples of $A$. fasciatus collected at different sites along Recôncavo Sul and Contas River basins, suggesting that this species could have a higher phenotypic plasticity than $A$. aff. bimaculatus. Furthermore, in the same report, the morphological data were supported by chromosomal differences (Medrado et al., 2008).
In the present work, the karyotypes of $A$. aff. bimaculatus populations were identical and the diploid number found $(2 n=50)$ is the same as described elsewhere for this species group. Actually, cytogenetic studies in several populations of $A$. bimaculatus and closely related species (e.g. Astyanax altiparanae) have also shown a chromosomal homogeneity, regarding both diploid number and karyotypic formula, when compared to other Astyanax species (Morelli et al., 1983; Fernandes \& Martins-Santos, 2004; Fernandes \& MartinsSantos, 2006; Domingues et al., 2007).

According to Oliveira et al. (2007), migratory rate and population density can influence the karyotypic macrostructure of a species. That is, the greater the mobility and number of individuals of a group, the more stable the karyotypic macrostructure will be, since gene flow would be higher and the fixation of chromosomal rearrangements hindered. Following 
this trend, representatives of the "bimaculatus-group" have been referred to as migratory and generalist species (Esteves $\&$ Galetti, 1995) and most of the studied populations usually maintain conserved macrokaryotypic features within the same hydrographic basin (Morelli et al., 1983; Paganelli, 1990 among others).

Nonetheless, the present data reveal that populations from the state of Bahia have a differentiated karyotypic formula in relation to other Brazilian hydrographic basins, indicating a high structural chromosomal diversity in the Astyanax group comprising the yellow-tailed characins. These results coupled with the available data in the literature (e.g., high chromosomal diversity, presence of distinct cytotypes and few cases of natural hybrid forms) can putatively indicate inter-specific differences, since Astyanax commonly comprises species complexes (see Pazza \& Kavalco, 2007 for a review).

Furthermore, banding techniques, such as Ag-NOR staining, could eventually indicate a higher degree of differentiation among apparent homogeneous populations (Kantek et al., 2007). In fact, the number and location of active NORs can be a useful tool to discriminate fish species and/or populations with similar karyotypes, as observed in A. altiparanae (Pacheco et al., 2001). The present results reinforce the polymorphic nature of the major ribosomal sites and the structural chromosomal variation usually detected in Astyanax species, since the number of Ag-NORs ranged from one to four signals. However, no cytogenetic populational marker was evident by analyzing the number and/or location of active NORs in this study, since they varied both within and among the populations of $A$. aff. bimaculatus studied. Moreover, it should be pointed out that the present cytogenetic results were based on conventional analyses. Additional studies using distinct and refined chromosomal markers could eventually reveal inter-population differences within each sample, as observed in several other studies within Astyanax (Fernandes \& MartinsSantos, 2006; Kantek et al., 2007 among others).

In spite of the high morphological and cytogenetic resemblance among the $A$. aff. bimaculatus populations studied, our molecular data revealed a significant populational structure $\left(\mathrm{F}_{\mathrm{st}}=0.1868\right)$. Curiously, a higher divergence level was observed between populations within Contas River Basin and isolated by the dam than between basins (Contas and Recôncavo Sul) (Table 5).

The levels of genetic differentiation among populations are supposed to reflect either their period or degree of isolation (Hartl \& Clark, 1989). Although recently constructed (nearly 40 years ago) (CRA, 2002; MMA, 2006a, b), Pedra Dam has been responsible for profound scenario changes (a former narrow fast-flowing river free from relevant physical barriers turned into an impounded reservoir) and already seems to represent an effective barrier to gene flow.

In the case of Neotropical fish, the few reports addressing the relationship between genetic structure of populations separated by artificial barriers (dams) and consequent differences in environmental features have found similar results. Hatanaka \& Galetti (2003), using RAPD markers in populations of Prochilodus marggravii in the São Francisco River Basin, revealed that the fish collected close to Três Marias Dam have a higher similarity coefficient than those from other downstream sites far from the dam. Additionally, significant differences in the band frequencies were observed among localities. According to the authors, both findings suggest the presence of structured populations in distinct natural $P$. marggravii stocks. The same scenario was observed in populations of another Neotropical fish species, Brycon lundii, where different allele frequencies were fixed upstream and downstream of Três Marias Dam (Wasko \& Galetti, 2002). Furthermore, the waters impounded after the construction of dams and reservoirs often provide a secondary contact between populations previously isolated (totally or partially) by natural obstacles. For instance, studies of genetic differentiation based on RAPD markers and coloration pattern in fish of the genus Steindachnerina from the upper Paraná River Basin indicated the occurrence of two different species. Spotted specimens were identified as Steindachnerina brevipinna, formerly found downstream of Sete Quedas Falls, suggesting that this species must have overcome the geographical barrier after the building of Itaipu Dam, which submerged the waterfalls - a former obstacle between upper and middle Paraná River basins (Oliveira et al., 2002). Similar evidence has also been reported in other fish species along this floodplain, such as Hemisorubim platyrhynchos (Prioli et al., 2004).

Apart from human-imposed environmental changes, particular biotic and abiotic features can also play a key role in the divergence pattern observed among populations. Environmental factors influence phenotypes both directly and indirectly, via trait correlations and interactions with other environmental variables, as demonstrated in several fish species (Langerhans et al., 2007). Analogously, they are also supposed to determine the genetic pattern of natural populations as well. A significant genetic differentiation among sites and no relationship between genetic differences and geographical distances were detected by RAPD markers in populations of the African cyprinid Barbus neumayeri. These data suggest that population structure is more related to habitat-specific selection pressures (different water flow and hypoxia levels per site) on dispersers, rather than insufficient dispersal (Chapman et al., 1999).

As a matter of fact, recent colonization and adaptation to new habits have been proved to affect the genetic structure of migratory fish and to result in fast reproductive isolation among populations. Genetic evidences for the salmonid fish Oncorhynchus nerka consistently showed that nearby populations introduced into divergent environments evolved to reproductively isolated "ecotypes" after fewer than 13 generations (Hendry et al., 2000). Considering that Astyanax species show remarkable ability to adapt to different habitats and a short life cycle (Garutti, 1989; Orsi et al., 2004), their populations may putatively change even faster.

If environmental features, whether natural or artificially imposed, are able to affect the genetic structure among populations of a species, the diversity pattern observed by molecular 
markers in the populations of $A$. aff. bimaculatus studied here are likely to reflect habitat peculiarities of each collection site. Actually, the first sampled area (site A) is located $70 \mathrm{~km}$ upstream of Pedra Dam, at the upper part of the reservoir in the Contas River. It represents a lotic and unpolluted ecosystem, surrounded by typical caatinga vegetation. Large specimens were easily collected at this site which usually indicates the occurrence of more suitable conditions for the development of local populations (Orsi et al., 2004). At collection site B (downstream of the dam, in Contas River), the natural environment is highly damaged by the daily oscillation in the water flow and by both domestic and industrial sewage from the city of Jequié (CRA, 2002). The third collection site (C), located in the Recôncavo Sul Basin, represents a small stream located in the Atlantic rainforest zone (see Fig. 2).

On the other hand, while particular environmental features may explain the differences observed among populations, especially within the same basin (sites A and B), historic facts can provide some insight about the close relationship between populations from distinct basins (Contas and Recôncavo Sul) (Table 5). Mineiro stream is located near Contas River (about $60 \mathrm{~km}$ apart), being separated by a small hill system with a putative common evolutionary history. Hypothetically, the occurrence of some past geological events in the area studied, such as headwater capture, could lead to genetic similarity between populations from currently separated (although adjacent) river basins. In fact, recent studies on biogeography in freshwater fishes along Brazilian coastal basins support the idea of an ancient connectivity among rivers from nearby areas (Pazza \& Kavalco, 2007). For instance, connectivity and divergence patterns in fish assemblages along southeastern drainages seem to be related to past tectonic movements (Ribeiro, 2006; Ribeiro et al., 2006). Moreover, a database of the quaternary faults and tectonic behavior over the last 1.6 millions of years along the Brazilian territory indicate that several geological events have taken place throughout the northeastern coast (Saadi et al., 2002). Unfortunately, the hydrographic systems in the state of Bahia and most of the northeastern region still lack specific studies focusing on their biogeographic or geological aspects, and thus, the present suggestions remain speculative.

Finally, despite the population structure detected herein, the intra-population genetic variability was higher (81.31\%) than among populations, showing that most of the variation refers to differences among individuals within populations. Similar results have been commonly reported by genetic studies with molecular markers in natural fish populations (Leuzzi et al., 2004; Paiva et al., 2006; Affonso \& Galetti, 2007). Other studies on small and isolated populations of domestic animals have also demonstrated such pattern, indicating that, even under inbreeding conditions, the levels of genetic variation within populations is usually higher than that observed among populations of a single species (e.g., Albuquerque et al., 2006).

The results of the present work are also important for highlighting the applicability of molecular markers in detecting differences within species characterized by a conservative morphological and/or cytogenetic pattern. Unlike from some other freshwater fish populations (e.g., Astyanax fasciatus) where distinct morphological and cytogenetic features have corroborated further molecular analyses (Pazza et al., 2007; Medrado et al., 2008), the populations of $A$. aff. bimaculatus studied here showed low levels of both morphometric and meristic differences and a similar karyotypic structure. Such lack of congruence between molecular and morphology/ karyotype data is commonly found in species composed of large and highly-connected populations (intense gene flow), such as marine fish (Galetti et al., 2006; Affonso \& Galetti, 2007). In these cases, the utilization of highly sensitive DNA markers is essential to help us understand how fish populations respond to natural selection or environmental changes caused by human activities, providing a useful baseline for the conservation and sustainable management of natural populations.

\section{Acknowledgements}

The authors thank Dr. Samuel Rezende Paiva and Dr. Alexandre C. Ribeiro for their assistance with statistical analyses and helpful comments, respectively. Financial support for this work was provided by CNPq, FAPESB, UESB and UESC.

\section{Literature Cited}

Affonso, P. R. A. M. \& P. M. Galetti Jr. 2007. Genetic diversity of three ornamental reef fishes (Families Pomacanthidae and Chaetodontidae) from the Brazilian coast. Brazilian Journal of Biology, 67(4, suppl.): 925-933.

Agostinho, A. A., L. M. Bini \& L. C. Gomes. 1997. Ecologia de comunidades de peixes da área de influência do reservatório de Segredo. Pp. 97-111. In: Agostinho, A. A. \& L. M. Gomes, (Eds.). Reservatório de Segredo, bases ecológicas para manejo. Maringá, EDUEM.

Agostinho, A. A., H. F. Julio Jr. \& J. R. Borghetti. 1992. Considerações sobre os impactos dos represamentos na ictiofauna e medidas para sua atenuação. Um estudo de caso: Reservatório de Itaipu. Revista da Unimar, 14: 89-107.

Albuquerque, M. S. M., A. A. Egito, J. R. F. Marques, A. Y. Ciampi, A. S. Mariante, S. T. R. Castro, M. R. Costa, S. R. Paiva, A. M. Silva \& E. P. B. Contel. 2006. Variabilidade genética em búfalos estimada por marcadores RAPD. Pesquisa Agropecuária Brasileira, 14(4): 623-628.

Avise, J. C. \& J. Felley. 1979. Population structure or freshwater fishes. I. Genetic variation of bluegill (Lepomis macrochirus) populations in man-made reservoirs. Evolution, 33: 15-26.

Bertollo, L. A. C., C. S. Takahashi \& O. Moreira-Filho. 1978. Cytotaxonomic considerations on Hoplias lacerdae (Pisces, Erythrinidae). Brazilian Journal of Genetics, 1: 103-120.

Boyce, T. M., M. E. Zwick \& C. F. Aquadro. 1989. Mitochondrial DNA in bark weevils: size, structure, and heteroplasmy. Genetics, 123: 825-836.

Chapman, L. J., C. A. Chapman, D. A. Brazeau, B. McLaughlin \& M. Jordan. 1999. Papyrus swamps, hypoxia, and faunal diversification: variation among populations of Barbus neumayeri. Journal of Fish Biology, 54: 310-327.

CRA - Centro de Recursos Ambientais. 2001. Recursos Hídricos. In: Avaliação da Qualidade das Águas. Relatório Técnico/Avaliação 
Ambiental. Salvador, Centro de Recursos Ambientais, 389p. (http://www.cra.ba.gov.br)

Domingues, M. S., M. R. Vicari, V. Abilhoa, J. P. Wanser, M. M. Cestari, L. A. C. Bertollo, M. C. Almeida, \& R. F. Artoni. 2007. Cytogenetic and comparative morphology of two allopatric populations of Astyanax altiparanae Garutti \& Britski, 2000 (Teleostei: Characidae) from upper rio Paraná basin. Neotropical Ichthyology, 5: 37-44.

Esteves, K. E. \& P. M. Galetti Jr. 1995. Food partitioning among some characids of a small Brazilian floodplain lake from the Paraná River basin. Environmental Biology of Fishes, 42: 375-389.

Excoffier, L., P. E. Smouse \& J. M. Quattro. 1992. Analysis of molecular variance inferred from metric distances among DNA haplotypes: application to human mitochondrial DNA data. Genetics, 131: 479-491.

Fernandes, C. A. \& I. C. Martins-Santos. 2004. Cytogenetic report in two populations of Astyanax altiparanae (Pisces, Characiformes). Hereditas, 141: 328-332.

Fernandes, C. A. \& I. C. Martins-Santos. 2006. Mapping of the 18 S and 5S ribosomal RNA genes in Astyanax altiparanae Garutti \& Britski, 2000 (Teleostei, Characidae) from the upper Paraná river basin, Brazil. Genetics and Molecular Biology, 29(3): 464-468.

Galetti Jr., P. M., W. F. Molina, P. R. A. M. Affonso \& C. T. Aguilar. 2006. Assessing genetic diversity of Brazilian reef fishes by chromosomal and DNA markers. Genetica, 126(1-2): 161-177.

Garutti, V. 1989. Contribuição ao conhecimento reprodutivo de $A s$ tyanax bimaculatus em cursos de água da bacia do rio Paraná. Revista Brasileira de Biologia, 49(2): 489-495.

Garutti, V. 1998. Descrição de uma espécie nova de Astyanax (Teleostei, Characidae) da bacia do Tocantins, Brasil. Iheringia, 85: $115-122$.

Garutti, V. \& H. A. Britski. 2000. Descrição de uma espécie nova de Astyanax (Teleostei: Characidae) da bacia do alto rio Paraná e considerações sobre as demais espécies do gênero na bacia. Comunicações do Museu de Ciência e Tecnologia da PUCRS, Série Zoologia, 13: 65-68.

Godinho, H. P. \& A. L. Godinho. 1994. Ecology and conservation of fish in southeastern Brazilian River basins submitted to hydroelectric impoundments. Acta Limnologica Braziliensia, 5: 187-197.

Hartl, D. L. \& A. G. Clark. 1997. Principles of Population Genetics. Massachussets, Sinauer Associates, Inc., 542p.

Hatanaka, T. \& P. M. Galetti Jr. 2003. RAPD markers indicate the occurrence of structured populations in a migratory freshwater fish species. Genetics and Molecular Biology, 26(1): 19-25.

Hendry, A. P., J. K. Wenburg, P. Bentzen, E. C. Volk \& T. P. Quinn. 2000. Rapid evolution of reproductive isolation in the wild: evidence from introduced salmon. Science, 290: 516-518.

Howell, W. M. \& D. A. Black. 1980. Controlled silver staining of nucleolus organizer region with protective colloidal developer: a 1-step method. Experientia, 36: 1014-1015.

Kantek, D. L. Z., R. B. Noleto, A. S. Fenocchio \& M. M. Cestari. 2007. Cytotaxonomy, heterochromatic polymorphism and natural triploidy of a species of Astyanax (Pisces, Characidae) endemic to the Iguaçu River basin. Brazilian Archives of Biology and Technology, 50: 67-74.

Lagler K. F., J. E. Bardach, R. R. Miller \& D. R. N. Passino. 1977. Ichthyology. New York, John Wiley \& Sons Ltd., 506p.

Langerhans, R. B., L. J. Chapman \& T. J. Dewitt. 2007. Complex phenotype-environment associations revealed in an East African cyprinid. Journal of Evolutionary Biology, 20(3): 1171-1181.

Leuzzi, M. S. P., F. S. Almeida, M. L. Orsi \& L. M. K. Sodré. 2004. Analysis by RAPD of the genetic structure of Astyanax altipara- nae (Pisces, Characiformes) in reservoirs on the Paranapanema River, Brazil. Genetics and Molecular Biology, 27(3): 355-362.

Levan A., K. Fredga \& A. A. Sandberg. 1964. Nomenclature for centromeric position on chromosomes. Hereditas, 52: 201-220.

Lynch, M. \& B. G. Milligan. 1994. Analysis of population genetic structure with RAPD markers. Molecular Ecology, 3: 91-99.

Medrado, A. S., A. V. A. Figueiredo, A. M. Waldschmidt, P. R. A. M. Affonso \& P. L. S. Carneiro. 2008. Cytogenetic and morphological diversity in populations of Astyanax fasciatus (Teleostei, Characidae) from Brazilian northeastern river basins. Genetics and Molecular Biology, 31 (1, suppl.): 208-214.

Miller, M. P. 1997. Tools for population genetics analyses (TFPGA): a Windows program for the analysis of allozyme and molecular population genetic data. (http://herb.bio.nau.edul miller/tfpga.htm).

Molina, W. F. 2001. An alternative method for mitotic stimulation in fish cytogenetics. Chromosome Science, 5: 149-152.

Molina, W. F., O. A. Shibatta \& P. M. Galetti Jr. 2006. Multivariate morphological analyses in continental and island populations of Abudefduf saxatilis (Linnaeus) (Pomacentridae, Perciformes) of Western Atlantic. Pan-American Journal of Aquatic Sciences, 1(2): 49-56.

Morelli, S., L. A. C. Bertollo, F. Foresti, O. Moreira-Filho \& S. A. Toledo-Filho. 1983. Cytogenetic considerations on the genus Astyanax (Pisces, Characidae). I. Karyotypic variability. Caryologia, 36: 235-244.

MMA - Ministério do Meio Ambiente. 2006a. Caderno da região hidrográfica Atlântico Leste. Ministério do Meio Ambiente, Secretaria de Recursos Hídricos (Ed.), Brasília, 156p.

MMA - Ministério do Meio Ambiente. 2006b. Plano Nacional de Recursos Hídricos. Panorama e estado dos recursos hídricos do Brasil: volume 1. Ministério do Meio Ambiente, Secretaria de Recursos Hídricos (Ed.), Brasília, 281p.

Oliveira, A. V., A. J. Prioli, S. M. A. P. Prioli, C. S. Pavanelli, H. F. Júlio Jr. \& R. S. Panarari. 2002. Diversity and genetic distance in populations of Steindachnerina in the Upper Paraná River floodplain of Brazil. Genetica, 115: 259-267.

Oliveira, C., L. F. Almeida-Toledo \& F. Foresti. 2007. Karyotypic evolution in Neotropical fishes. Pp. 111-163. In: Pisano E., C. Ozouf-Costaz \& F. Foresti (Eds.). Fish Cytogenetics. Enfield, Science Publisher Inc.

Orsi, M. L, E. D. Carvalho \& F. Foresti. 2004. Biologia populacional de Astyanax altiparanae Garutti \& Britski (Teleostei, Characidae) do médio Rio Paranapanema, Paraná, Brazil. Revista Brasileira de Zoologia, 21(2): 207-218.

Pacheco, R. B., L. Giuliano-Caetano \& A. L. Dias. 2001. Cytotypes and multiple NORs in an Astyanax altiparanae population (Pisces, Tetragonopterinae). Chromosome Science, 5: 109-114.

Paganelli, H. H. 1990. Diversidade cromossômica no gênero Astyanax, com especial referência a A. bimaculatus. (Linnaeus, 1758). Considerações citotaxonômicas e evolutivas. Unpublished Master's dissertation, Universidade Federal de São Carlos, São Paulo, 115p.

Paiva, M. P. 1982. Grandes represas do Brasil. Editerra Editorial, Brasília, 304p.

Paiva, S. R., J. A. Dergam \& F. Machado. 2006. Determining management units in northeastern Brazil: the case of Astyanax bimaculatus (Linnaeus, 1758) (Teleostei: Ostariophysi: Characidae). Hydrobiologia, 560: 393-404.

Pazza, R. \& K. F. Kavalco. 2007. Chromosomal evolution in the neotropical characin Astyanax (Teleostei, Characidae). The nucleus, 50(3): 519-543.

Pazza, R., K. F. Kavalco, S. M. A. P. Prioli, A. J. Prioli \& L. A. C. Bertollo. 2007. Chromosome polymorphism in Astyanax fasciatus (Teleostei, Characidae), Part 3: Analysis of the RAPD 
and ISSR molecular markers. Biochemical Systematics and Ecology, 35: 843-851.

Pianka, E. R. 1974. Niche overlap and diffuse competition. Proceedings of the National Academic Sciences, 71: 2141-2145.

Prioli, A. J., J. C. Galdino, S. M. A. P. Prioli, T. C. Maniglia, L. C. Lucio, H. F. Júlio Jr \& L. M. Prioli. 2004. Genetic distances among populations of Leporinus elongatus (Characiformes) and Hemisorubim platyrhynchos (Siluriformes) originally isolated by the Sete Quedas Falls. Pp. 133-136. In: Agostinho, A. A., L. Rodrigues \& L. C. Gomes (Eds.). The Upper Paraná River Floodplain: Structure and Process. EDUEM, Maringá.

Rapini, A., L. P. Queiroz \& A. M. Giulietti. 2006. PPBIO: The Program of Research on Biodiversity in the Brazilian Semi-arid. Pp. 27-32. In: Queiroz, L. P., A. Rapini \& A. M. Giulietti (Eds.). Towards greater knowledge of the Brazilian semi-arid biodiversity. Brasília, Ministério do Meio Ambiente.

Ribeiro, A. C. 2006. Tectonic history and the biogeography of the freshwater fishes from the coastal drainages of eastern Brazil: an example of faunal evolution associated with a divergent continental margin. Neotropical Ichthyology, 4(2): 225-246.

Ribeiro. A. C., F. C. T. Lima, C. Riccomini \& N. A. Menezes. 2006. Fishes of the Atlantic Rainforest of Boracéia: testimonies of the Quaternary fault reactivation within a Neoproterozoic tectonic province in Southeastern Brazil. Ichthyological Exploration of Freshwaters, 17(2): 157-164.

Rosa, R. S. 2004. Diversidade e conservação dos peixes da caatinga. Pp. 149-161. In: Silva, J. M. C., M. Tabarelli, M. T. Fonseca \& L. V. Lins (Eds.). Biodiversidade da Caatinga: Áreas e Ações Prioritárias para a Conservação. Brasília, Ministério do Meio Ambiente.

Rosa, R. S., N. A. Menezes, H. A. Britski, W. J. E. M. Costa \& F. Groth. 2003. Diversidade, padrões de distribuição e conservação dos peixes da caatinga. Pp. 135-180. In: Leal, I. R., M. Tabarelli \& J. M. C. Silva (Eds.). Ecologia e Conservação da Caatinga. Recife, Editora Universitária da Universidade Federal de Pernambuco.

Saadi, A., M. N. Machette, K. M. Haller, R. L. Dart, L. Bradley \& A. M. P. D. Souza. 2002. Map and database of Quaternary faults and lineaments in Brazil. U.S. Geological Survey, Open-File Report 02-230. (http://pubs.usgs.gov/of/2002/ofr-02-230).
SAS - Statistical Analysis System. 2004. User's Guide, Version 9. Cary, SAS Institute Inc.

Schneider, S., D. Roessli \& L. Excoffier. 2000. ARLEQUIN ver 2.000: a software for population genetics data analysis. University of Geneva, Genetic and Biometry Laboratory, Geneva. (http://www.anthropologie.unige.ch/arlequin).

SRHSH - Secretaria dos Recursos Hídricos, Saneamento e Habitação. 1993. Plano Diretor de Recursos Hídricos Bacia do rio das Contas: diagnóstico do sistema físico. Relatório Técnico. Salvador, Governo do Estado da Bahia, 160p.

Vono, V., L. G. M. Silva, B. P. Maia \& H. P. Godinho. 2002. Biologia reprodutiva de três espécies simpátricas de peixes neotropicais: Pimelodus maculatus Lacépède (Siluriformes, Pimelodidae), Leporinus amlyrhynghus Garavello \& Britski e Schizodon nasutus Kner (Characiformes, Anostomidae) do recém-formado Reservatório de Miranda, Alto Paraná. Revista Brasileira de Zoologia, 19: 819-826.

Vrijenhoek, R. C. 1998. Conservation genetics of freshwater fish. Journal of Fish Biology, 53: 394-412.

Wasko, A. P. \& P. M. Galetti Jr. 2002. RAPD analysis in the Neotropical fish Brycon lundii: genetic diversity and its implications for the conservation of the species. Hydrobiologia, 474(1-3): 131-137.

Welcomme, R. L., K. O. Winemiller \& I. G. Cowx. 2005. Ecological guilds as a tool for environmental impact assessment in Rivers. River Research and Applications, 21: 1-20.

Williams, J. G. K., A. R. Kubelik, K. J., Livak, J. A. Rafalski \& S. V. Tingey. 1990. DNA polymorphisms amplified by arbitrary primers are useful as genetic markers. Nucleic Acids Research, 18(22): 6531-6535.

Winemiller, K. O. \& M. A. Leslie. 1992. Fish communities across a complex freshwater-marine ecotone. Environmental Biology of Fishes, 34: 29-50.

Wright, S. 1978. Evolution and genetics of populations. Vol. 4: Variability Within and Among Natural Populations. London, University of Chicago Press. 590p.

Accepted July 2008

Published December 22, 2008 